\title{
Analisis Kemampuan Pemecahan Masalah Siswa SMP Kelas VIII Pada Materi Bangun Ruang Sisi Datar Ditinjau dari Kecerdasan Logis Matematis
}

\author{
Riyani Rinawati ${ }^{1}$, Novisita Ratu ${ }^{2}$ \\ 1,2 Program Studi Pendidikan Matematika, Fakultas Keguruan dan Ilmu Pendidikan, Universitas Kristen Satya Wacana, \\ J1. Diponegoro No 52-60, Salatiga, Kec.Sidorejo, Kota Salatiga, Jawa Tengah 50711 \\ 202017055@student.uksw.edu
}

\begin{abstract}
This research aims to analyze the problem-solving abilities of class VIII students of SMP Negeri 1 Pabelan on the flat sided geometry material in terms of mathematical logical intelligence. This research is a qualitative research conducted from February to April 2021. The subjects in the study were 3 students of class VIII, consisting of students with high, medium, and low levels of mathematical logical intelligence. The data was collected by means of tests, interviews, and documentation. Based on the results of data analysis, it was found that (1) students with high mathematical logical intelligence were able to go through the stages of understanding the problem for questions number 1 and number 2, planning problem solving for questions number 1 and number 2, implementing problem solving plans for questions number 1 and number 2 , but unable to check again for questions number 1 and number 2, (2) students with mathematical logical intelligence are able to go through the stages of understanding the problem for questions number 1 and number 2, planning problem solving for questions number 1 and number 2, implementing problem solving plan for question number 1 and unable to number 2 , and unable to check again for questions number 1 and number 2, (3) students with low mathematical logical intelligence are only able to go through the stages of understanding the problem.
\end{abstract}

Keywords: Mathematical Logical Intelligence, Students Problem Solving Ability

\begin{abstract}
Abstrak
Penelitian ini bertujuan untuk menganalisis kemampuan pemecahan masalah siswa kelas VIII SMP Negeri 1 Pabelan pada materi bangun ruang sisi datar ditinjau dari kecerdasan logis matematis. Penelitian ini merupakan penelitian kualitatif yang dilakukan mulai Februari - April 2021. Subjek dalam penelitian adalah 3 siswa kelas VIII, terdiri dari siswa tingkat kecerdasan logis matematis tinggi, sedang, dan rendah. Pengumpulan data dilakukan dengan metode tes, wawancara, dan dokumentasi. Berdasarkan hasil analisis data diperoleh bahwa (1) siswa dengan kecerdasan logis matematis tinggi mampu melalui tahapan memahami masalah untuk soal nomor 1 dan nomor 2, merencanakan pemecahan masalah untuk soal nomor 1 dan nomor 2, melaksanakan rencana pemecahan masalah untuk soal nomor 1 dan nomor 2 , namun tidak mampu memeriksa kembali untuk soal nomor 1 dan nomor 2, (2) siswa dengan kecerdasan logis matematis sedang mampu melalui mampu melalui tahapan memahami masalah untuk soal nomor 1 dan nomor 2, merencanakan pemecahan masalah untuk soal nomor 1 dan nomor 2 , melaksanakan rencana pemecahan masalah untuk soal nomor 1 dan tidak mampu untuk nomor 2, dan tidak mampu memeriksa kembali untuk soal nomor 1 dan nomor 2, (3) siswa dengan kecerdasan logis matematis rendah hanya mampu melalui tahapan memahami masalah.
\end{abstract}

Kata kunci: Kecerdasan Logis Matematis, Kemampuan Pemecahan Masalah Siswa

Copyright (c) 2021 Riyani Rinawati, Novisita Ratu

Corresponding author: Riyani Rinawati

Email Address: 202017055@student.uksw.edu (Jl. Diponegoro No 52-60, Salatiga, Kec.Sidorejo, Salatiga)

Received 27 April 2021, Accepted 03 May 2021, Published 10 May 2021

\section{PENDAHULUAN}

Matematika menjadi salah satu mata pelajaran yang diajarkan sejak jenjang SD, SMP, SMA kepada siswa. Hal tersebut tidak dapat dipungkiri bahwa matematika merupakan pelajaran yang penting bagi siswa, selain itu matematika juga menjadi salah satu mata pelajaran yang masuk dalam Ujian Nasional pada setiap tahun. Pada saat proses pembelajaran matematika, terdapat beberapa aspek yang dapat dikembangkan untuk meningkatkan kualitas siswa, salah satunya adalah kemampuan pemecahan masalah. Seperti yang tercantum dalam Permendikbud No.22 Tahun 2006 Mengenai Standar Isi Untuk 
Satuan Pendidikan Dasar Dan Menengah salah satunya berbunyi Mempunyai sikap menghargai manfaat matematika dalam mempelajari masalah, serta sikap giat dan percaya diri dalam pemecahan masalah. Pernyataan tersebut memperkuat bahwa kemampuan pemecahan masalah dalam pembelajaran matematika sangatlah penting.

Kemampuan pemecahan masalah merupakan kemampuan yang wajib dimiliki oleh siswa supaya siswa mampu menyelesaikan proses pemecahan masalah yang dihadapi. Menurut (Hidayat \& Sariningsih, 2018), kemampuan pemecahan masalah merupakan salah satu tujuan dari pembelajaran matematika yang harus dicapai oleh siswa. Menurut (Sumartini \& Matematis, 2016), kemampuan pemecahan masalah siswa diasah melalui masalah yang bertujuan untuk meningkatkan berbagai kompetensi yang dimilikinya. Sedangkan menurut (Mariam et al., 2019) kemampuan pemecahan masalah harus dimiliki oleh siswa dengan tujuan agar siswa terbiasa menyelesaikan masalah yang diberikan oleh guru. Berdasarkan pendapat di atas, dapat disimpulkan bahwa kemampuan pemecahan merupakan salah satu keahlian yang wajib dimiliki oleh siswa bertujuan agar siswa mudah menyelesaiakan setiap permasalahan yang dihadapinya, selain itu dalam bidang pelajaran matematika siswa selalu dihadapkan dengan permasalahan yang diperoleh dari soal. Menurut Polya dalam (Nissa, 2015) terdapat empat tahapan dalam proses pemecahan masalah antara lain memahami masalah (see), menyusun rencana pemecahan masalah (plan), melaksanakan rencana pemecahan masalah (do), dan memeriksa kembali (check).

Namun pada kenyataannya kemampuan pemecahan masalah pada siswa di Indonesia masih tergolong rendah. Berdasarkan hasil survei yang dilakukan oleh survei internasional PISA (Progam for International Student Assessment) tahun 2012, dimana Indonesia menduduki peringkat 64 dari 65 negara peserta PISA (OECD, 2012). Pada tahun 2015, Indonesia masih menduduki peringkat 56 dari 65 negara peserta PISA dalam kemampuan menghitung, membaca, dan sains (OECD, 2015). Sedangkan hasil survey TIMSS pada tahun 2011 Indonesia menduduki peringkat 38 dari 42 negara (Cahyono \& Adilah., 2016). Setiap siswa memiliki kemampuan pemecahan masalah yang berbeda-beda, hal tersebut dikarenakan beberapa faktor baik faktor eksternal maupun faktor internal. Irawan dkk dalam (Komang et al., 2018), mengatakan bahwa pengetahuan awal, apresiasi matematika, dan kecerdasan logis matematis mampu mempengaruhi kemampuan pemecahan masalah matematika.

Kecerdasan logis matematis adalah kecerdasan seseorang dalam berpikir secara deduktif dan induktif, berpikir berdasarkan aturan logika, memahami dan menganalisis pola-pola, serta kemampuan berpikir untuk memecahkan masalah (Faizah et al., 2017). Kecerdasan logis matematis dapat diartikan sebagai kemampuan seseorang untuk berpikir secara logis dalam memecahkan permasalahan dan melakukan perhitungan secara matematis (Asis et al., 2015). Sedangkan menurut (Susanti, 2018.), kecerdasan logis matematis adalah kemampuan sesorang dalam bernalar baik secara induktif ataupun deduktif, bernalar berdasarkan akal sehat dalam menafsirkan dan menelaah pola, juga dalam menyelesaikan masalah. Orang yang memiliki kecerdasan logis matematis mampu menyelesaikan masalah dengan baik (Mahardhikawati et al., 2017). Berdasarkan penjelasan di atas, kecerdasan logis 
matematis merupakan kecerdasan yang berkaitan dengan kemampuan seseorang dalam menyelesaikan pemecahan masalah yang meliputi penalaran deduktif dan induktif, penalaran pola-pola, dan berpikir logis. Dengan demikian, pemecahan masalah mempunyai kaitan dengan kecerdasan logis matematis seseorang. Selain itu, kecerdasan logis matematis digunakan siswa dalam proses pemecahan masalah.

Terdapat beberapa materi yang dapat digunakan untuk menyajikan masalah yang berkaitan dengan kemampuan pemecahan masalah pada proses pembelajaran matematika, sebagai contohnya adalah materi bangun ruang sisi datar. Pada materi ini siswa masih sering kesulitan dalam menyelesaikan soal. Untuk membedakan penelitian ini dengan penelitian lain, peneliti memilih materi bangun ruang sisi datar terutama pada konten kubus dan balok. Fokus permasalahan soal hanya pada mencari volume kubus dan volume balok yang direpresentasikan dalam bentuk soal cerita yang berkaitan dengan kehidupan sehari-hari.

Penelitian ini bertujuan untuk menganalisis kemampuan pemecahan masalah pada siswa SMP kelas VIII yang ditinjau dari kecerdasan logis matematis. Dalam penelitian ini, peneliti memilih materi bangun ruang sisi datar khusus pada sub materi kubus dan balok dengan konteks soal cerita. Alasan peneliti memilih materi tersebut karena siswa masih kesulitan dalam menyelesaikan soal terkait materi tersebut. Pada tahap pemecahan masalah, peneliti memilih teori pemecahan masalah berdasarkan teori G.Polya.

\section{METODE}

Jenis penelitian yang digunakan dalam penelitian ini adalah penelitian deskriptif kualitatif. Menurut Sugiyono (2015), penelitian kualitatif merupakan suatu metode penelitian yang berfungsi untuk memastikan kebenaran suatu data yang berawal dari masalah karena terdapat keraguan terhadap adanya informasi tertentu.

Sumber data dalam penelitian ini adalah hasil wawancara terhadap siswa kelas VIII SMP Negeri 1 Pabelan dan hasil tertulis tes kemampuan pemecahan masalah. Data utama dalam penelitian ini berupa kemampuan pemecahan masalah siswa yang diperoleh dari hasil tes kemampuan pemecahan masalah siswa. Sedangkan data pendukung berupa data dari hasil tes kecerdasan logis matematis.

Pada penelitian ini cara pengambilan subjek dalam penelitian ini adalah dengan menggunakan cara purposive sampling, yaitu teknik pengambilan subjek dipilih berdasarkan kriteria tertentu. Subjek dipilih berdasarkan pertimbangan guru dengan kriteria sebagai berikut: (1) siswa kelas VIII dengan tingkat kecerdasan logis tinggi, sedang, dan rendah; (2) subjek mampu bekerjasama baik dengan peneliti; (3) subjek mampu berkomunikasi dengan baik. Adapun jadwal kegiatan penelitian sebagai berikut.

Tabel 1. Rencana Kegiatan Penelitian

\begin{tabular}{|l|l|c|c|c|c|c|c|c|c|}
\hline \multirow{2}{*}{ No } & \multicolumn{4}{|c|}{ Kegiatan } & \multicolumn{4}{|c|}{ 2020 } & \multicolumn{5}{|c|}{2021} \\
\cline { 3 - 10 } & & Jan & Feb & Mar & Apr & Jan & Feb & Mar & Apr \\
\hline 1 & Penyusunan proposal penelitian & $\sqrt{ }$ & $\sqrt{ }$ & $\sqrt{ }$ & & & & & \\
\hline 2 & Penyusunan instrumen & & & & $\sqrt{ }$ & $\sqrt{ }$ & $\sqrt{ }$ & & \\
\hline
\end{tabular}




\begin{tabular}{|l|l|l|l|l|l|l|l|l|c|}
\hline 3 & Validasi instrumen & & & & & & $\sqrt{ }$ & $\sqrt{ }$ & \\
\hline 4 & Pengambilan data & & & & & & $\sqrt{ }$ & $\sqrt{ }$ & $\sqrt{ }$ \\
\hline 5 & Menganalisis data & & & & & & & $\sqrt{ }$ & $\sqrt{ }$ \\
\hline 6 & Membuat laporan penelitian & & & & & & $\sqrt{ }$ & $\sqrt{ }$ & \\
\hline 7 & Penyusunan jurnal ilmiah & & & & & & & $\sqrt{ }$ & $\sqrt{ }$ \\
\hline 8 & Publikasi & & & & & & & & $\sqrt{ }$ \\
\hline
\end{tabular}

Teknik pengumpulan data pada penelitian ini berupa tes dan wawancara. Dalam penelitian ini terdapat dua tes yaitu tes kecerdasan logis matematis dan tes kemampuan pemecahan masalah. Tes kecerdasan logis matematis dilaksanakan pada tahap awal yang bertujuan untuk mengelompokkan subjek berdasarkan tingkat kecerdasan logis matematis tinggi, sedang, dan rendah. Selain itu penentuan subjek juga berdasarkan pertimbangan guru. Berdasarkan tes kecerdasan logis matematis diperoleh subjek S1 dengan tingkat kecerdasan logis matematis tinggi, subjek S2 dengan tingkat kecerdasan logis matematis sedang, dan subjek S3 dengan tingkat kecerdasan logis matematis rendah. Kemudian tes kemampuan pemecahan masalah dilakukan oleh subjek terpilih yaitu subjek $S 1$, subjek $S 2$, dan subjek S3 yang bertujuan untuk menganalisis kemampuan pemecahan masalah. Sedangkan wawancara bertujuan untuk menggali informasi tentang kemampuan pemecahan masalah siswa. Metode wawancara yang digunakan dalam penelitian ini adalah wawancara tak terstruktur. Pertanyaan disesuaikan dengan keadaan subjek dengan terlebih dahulu mempersiapkan pertanyaan yang dituangkan dalam pedoman wawancara.

Instrumen utama dalam penelitian ini adalah peneliti sendiri, sedangkan instrumen pendukung yang digunakan antara lain tes kecerdasan logis matematis dengan melakukan uji validasi dan reliabilitas menggunakan SPPS, tes kemampuan pemecahan masalah matematika terkait dengan bangun ruang sisi datar dan pedoman wawancara dimana semua instrumen telah dinyatakan valid oleh validator.

\section{HASIL DAN DISKUSI}

Berdasarkan hasil tes kemampuan pemecahan masalah siswa kelas VIII pada materi bangun ruang sisi datar ditinjau dari kecerdasan logis matematis diperoleh data sebagai berikut.

Tabel 2. Hasil Tahapan Pemecahan Masalah teori Polya berdasarkan Hasil Pekerjaan dan Wawancara terhadap Subjek

\begin{tabular}{|c|c|c|c|c|c|c|c|c|}
\hline \multirow{4}{*}{ No } & \multirow{4}{*}{$\begin{array}{c}\text { Tahap Pemecahan } \\
\text { Masalah }\end{array}$} & \multirow{4}{*}{ Indikator } & \multicolumn{6}{|c|}{ Subjek } \\
\hline & & & \multirow{2}{*}{\multicolumn{2}{|c|}{ S1 }} & \multicolumn{2}{|c|}{ S2 } & \multicolumn{2}{|c|}{ S3 } \\
\hline & & & & & \multicolumn{4}{|c|}{ Soal } \\
\hline & & & 1 & 2 & 1 & 2 & 1 & 2 \\
\hline 1. & Memahami masalah (see) & $\begin{array}{l}\text { Siswa mampu memahami masalah } \\
\text { yang terdapat pada soal }\end{array}$ & $\sqrt{ }$ & $\sqrt{ }$ & $\sqrt{ }$ & $\sqrt{ }$ & $\sqrt{ }$ & $\sqrt{ }$ \\
\hline 2. & $\begin{array}{l}\text { Menyusun rencana } \\
\text { pemecahan masalah } \\
\text { (plan) }\end{array}$ & $\begin{array}{l}\text { Siswa mampu menyusun rencana } \\
\text { penyelesaian dari masalah yang } \\
\text { terdapat pada soal }\end{array}$ & $\sqrt{ }$ & $\sqrt{ }$ & $\sqrt{ }$ & $\sqrt{ }$ & $\mathrm{X}$ & $\mathrm{X}$ \\
\hline 3. & $\begin{array}{l}\text { Melaksanakan rencana } \\
\text { pemecahan masalah }(d o)\end{array}$ & $\begin{array}{l}\text { Siswa mampu melaksanakan rencana } \\
\text { yang telah disusun }\end{array}$ & $\sqrt{ }$ & $\sqrt{ }$ & $\sqrt{ }$ & $\mathrm{X}$ & $\mathrm{X}$ & $\mathrm{X}$ \\
\hline
\end{tabular}




\begin{tabular}{|l|l|l|l|l|l|l|l|l|}
\hline 4. & $\begin{array}{l}\text { Memeriksa kembali } \\
\text { (check })\end{array}$ & $\begin{array}{l}\text { Siswa mampu memeriksa kembali } \\
\text { jawaban yang telah diperoleh dan } \\
\text { membuat kesimpulan }\end{array}$ & $\mathrm{X}$ & $\mathrm{X}$ & $\mathrm{X}$ & $\mathrm{X}$ & $\mathrm{X}$ & $\mathrm{X}$ \\
\hline
\end{tabular}

Adapun pembahasan berdasarkan hasil pekerjaan subjek mengenai kemampuan pemecahan masalah menurut teori Polya sebagai berikut.

\section{Deskripsi Soal Nomor 1}

Perhatikan gambar di bawah ini!

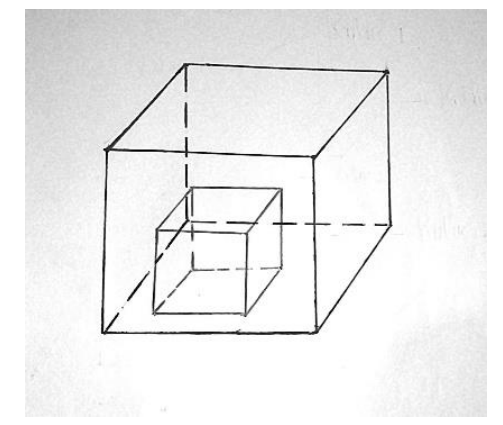

Terdapat dua kubus berisi air dengan perbandingan volume 1:4. Jika kubus besar memiliki volume air $1372 \mathrm{~cm}^{3}$, maka berapa panjang sisi kubus kecil?

\section{Subjek $\mathrm{S1}$}

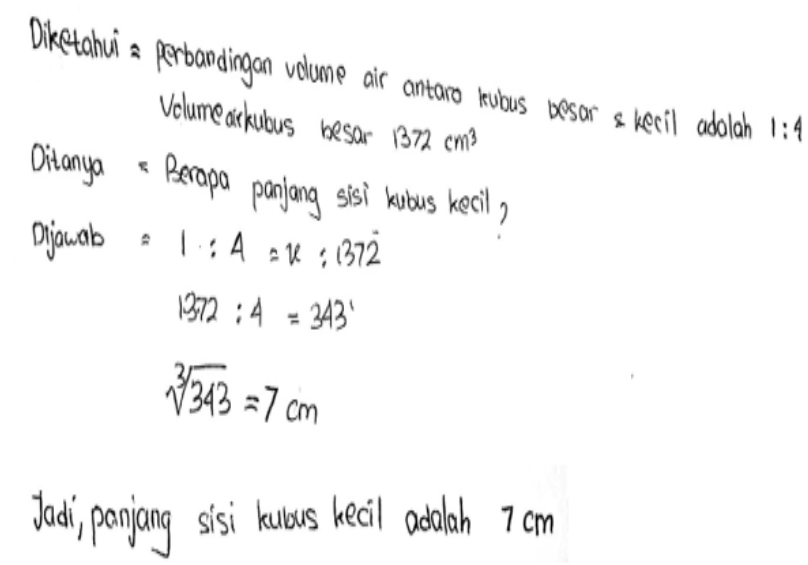

Gambar 1. Hasil Pekerjaan dan Wawancara Subjek S1 Soal Nomor 1

\section{Memahami masalah (See)}

S1: Nomor 1 diketahui perbandingan volume air kubus kecil dan kubus besar yaitu 1:4, lalu volume air dari kubus besar yaitu $1372 \mathrm{~cm}^{3}$.

S1: Lalu yang ditanyakan dari soal yaitu berapa panjang sisi kubus kecil.

\section{Menyusun rencana pemecahan masalah (Plan)}

S1: Pertama mencari volume kubus kecil dulu bu. Nah volume kubus kecilnya itu saya misalkan x bu.

S1: Saya tulis $1: 4=x: 1372$ (sambil menunjukkan jawaban). Lalu 1372 dikalikan dengan 1 hasilnya 1372, terus x dikalikan dengan 4 jadinya 4x. Kemudian 4x sama dengan 1372, nah 1372 dibagi 4 
untuk mencari nilai $x$ bu, hasilnya $343 \mathrm{~cm}^{3}$. Jadi volume air kubus kecil itu $343 \mathrm{~cm}^{3}$ bu

\section{Melaksanakan rencana pemecahan masalah (Do)}

S1: Kan diperoleh volume air kubus kecil $343 \mathrm{~cm}^{3}$ bu, terus volumenya saya akar pangkat tiga sehingga diperoleh hasil $7 \mathrm{~cm}$ (sambil menunjukkan jawaban).

S1: Kan rumus volume sisi kali sisi kali sisi $(\mathrm{s} \times \mathrm{s} \times \mathrm{s})$ bu, jadi untuk mencari salah satu sisinya ya sama saja akar pangkat tiga dari volume kubus kecil.

\section{Memeriksa kembali (Check)}

S1: Saya kerjakan dua kali bu.

Berdasarkan hasil tes dan wawancara soal nomor 1 pada subjek S1 menyelesaikan soal bangun ruang sisi datar konten volume kubus dan volume balok menggunakan langkah-langkah pemecahan masalah teori Polya. Pada tahap pertama subjek S1 mampu melalui tahap memahami masalah (see) sebagaimana terlihat bahwa subjek mampu menentukan apa yang diketahui yaitu perbandingan volume kubus kecil dan kubus besar 1:4, volume kubus besar $1372 \mathrm{~cm}^{3}$, dan apa yang ditanyakan pada soal yaitu mencari panjang sisi kubus kecil. Selain itu, subjek juga mampu mengidentifikasi informasi apa saja yang diperoleh dari soal untuk menjawab pertanyaan yang diberikan. Pada tahap kedua dalam menyusun rencana pemecahan masalah (plan) subjek S1 mampu menggunakan semua informasi yang terdapat pada soal serta dapat menentukan strategi untuk menyelesaikan soal tersebut dengan cara mencari volume kubus kecil terlebih dahulu dan memisalkannya dengan $\mathrm{x}$, kemudian subjek menjelaskan langkah-langkah penyelesaian dengan menulis $1: 4=x: 1372$, kemudian 1372 dikalikan 1 sama dengan 1372 dan x dikalikan dengan 4 sama dengan 4x. Kemudian 1372 dibagi 4 untuk mencari nilai $\mathrm{x}$ hasilnya $343 \mathrm{~cm}^{3}$. Pada tahap ketiga dalam melaksanakan rencana pemecahan masalah (do) subjek S1 mampu menggunakan rencana pemecahan masalah yang sudah disusun pada tahap sebelumnya untuk menyelesaikan soal. Namun pada tahap keempat dalam memeriksa kembali (check) subjek S1 tidak mampu memeriksa kembali hasil pekerjaannya. Pada tahap ini subjek hanya mengecek kembali hasil pekerjaannya dengan cara dikerjakan dua kali.

\section{$\underline{\text { Subjek S2 }}$}

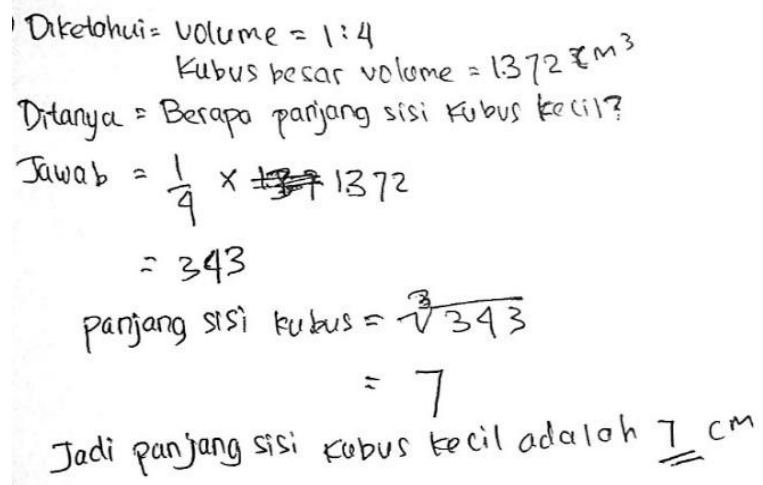

Gambar 2. Hasil Pekerjaan dan Wawancara Subjek S2 Soal Nomor 1 


\section{Memahami masalah (See)}

S2: Pada soal momor 1 diketahui ada dua kubus dengan perbandingan volume kubus kecil dan volume kubus besar 1:4, selain itu volume air dari kubus besar yaitu $1372 \mathrm{~cm}^{3}$.

S2: Yang ditanyakan adalah panjang sisi kubus kecil.

\section{Menyusun Rencana Pemecahan Masalah (Plan)}

S2: Saya mencari volume kubus kecil dulu bu.

S2: Saya menggunakan perbandingan volume dua kubus $1: 4$ ditulis $\frac{1}{4}$, terus volume kubus kecil saya misalkan $x$ bu, lalu saya lakukan perbandingan dua kubus sama dengan perbandingan volume kubus kecil dan volume kubus besar, ditulis 1:4 = x : 1372. Kemudian 1 dikali 1372 sama dengan 1372, dan 4 dikali x sama dengan 4x. Kemudian untuk mencari x caranya 1372 dibagi 4 diperoleh hasil 343. jadi volume kubus kecil adalah $343 \mathrm{~cm}^{3}$

\section{Melaksanakan rencana pemecahan masalah (Do)}

S2: Setelah diperoleh volume air kubus kecil $343 \mathrm{~cm}^{3}$ terus dibuat akar pangkat tiga hasilnya $7 \mathrm{~cm}$ bu. (sambil menunjukkan jawaban).

S2: Dari rumus volume sisi kali sisi kali sisi $(\mathrm{s} \times \mathrm{s} \times \mathrm{s})$ bu, jadinya kan sama saja akar pangkat tiga untuk mencari sisinya.

\section{Memeriksa kembali (Check)}

S2: Tadi saya sudah mengecek lagi bu.

Berdasarkan hasil tes dan wawancara soal nomor 1 pada subjek S2 menyelesaikan soal bangun ruang sisi datar konten volume kubus dan volume balok menggunakan langkah-langkah pemecahan masalah teori Polya. Pada tahap pertama subjek S2 mampu melalui tahap memahami masalah (see) sebagaimana terlihat bahwa subjek mampu menentukan apa yang diketahui yaitu ada dua kubus dengan perbandingan volume kubus kecil dan volume kubus besar 1:4, selain itu volume air dari kubus besar yaitu $1372 \mathrm{~cm}^{3}$, dan apa yang ditanyakan yaitu panjang sisi kubus kecil. Selain itu, subjek juga mampu mengidentifikasi informasi apa saja yang diperoleh dari soal untuk menjawab pertanyaan yang diberikan. Pada tahap kedua dalam menyusun rencana pemecahan masalah (plan) subjek S2 mampu menggunakan semua informasi yang terdapat pada soal serta dapat menentukan strategi untuk menyelesaikan soal tersebut dengan cara mencari volume kubus kecil terlebih dulu, kemudian subjek menggunakan perbandingan volume dua kubus 1:4 ditulis $\frac{1}{4}$ dan memisalkan volume kubus kecil sebagai x. Langkah selanjutnya subjek membuat perbandingan dua kubus sama dengan perbandingan volume kubus kecil dan volume kubus besar yang ditulis $1: 4=\mathrm{x}: 1372$. Kemudian melakukan perkalian 1 dengan 1372 dan 4 dengan x. Setelah itu mencari nilai x dengan cara 1372 dibagi 4 diperoleh hasil 343 sebagai nilai volume kubus kecil. Pada tahap ketiga dalam melaksanakan rencana pemecahan masalah (do) subjek S2 mampu menggunakan rencana pemecahan masalah yang sudah disusun pada tahap sebelumnya untuk menyelesaikan soal dengan cara mengakar pangkat tiga volume kubus kecil dan diperoleh hasil $7 \mathrm{~cm}$ sebagai panjang sisi kubus kecil. Namun pada tahap keempat dalam memeriksa 
kembali (check) subjek S2 tidak mampu memeriksa kembali hasil pekerjaannya. Pada tahap ini subjek hanya meneliti hasil pekerjaannya.

\section{$\underline{\text { Subjek S3 }}$}

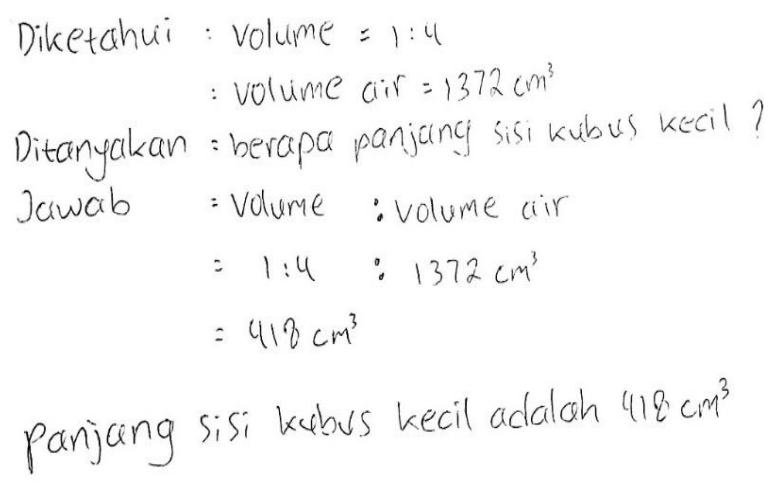

Gambar 3. Hasil Pekerjaan dan Wawancara Subjek S3 Soal Nomor 1

\section{Memahami masalah (See)}

S3: Lalu diketahui volume air kubus besar $1372 \mathrm{~cm}^{3}$, dan perbandingan volume kubus kecil dan kubus besar yaitu 1:4, yang ditanyakan dari soal yaitu berapa panjang sisi kubus kecil bu.

\section{Menyusun Rencana Pemecahan Masalah (Plan)}

S3: Saya membagi volume air kubus besar itu bu.

S3: Itu kan perbandingan volume 1:4 bu, terus volume kubus besar saya bagi 4 dan hasilnya $418 \mathrm{~cm}^{3}$.

\section{Melaksanakan Rencana Pemecahan Masalah (Do)}

S3: Iya bu. Itukan sudah ketemu panjang sisi kubus kecilnya bu. Hasilnya adalah $418 \mathrm{~cm}^{3}$.

\section{Memeriksa Kembali (Check)}

\section{S3: Tidak.}

Berdasarkan hasil tes dan wawancara soal nomor 1 pada subjek S3 menyelesaikan soal bangun ruang sisi datar konten volume kubus dan volume balok menggunakan langkah-langkah pemecahan masalah teori Polya. Pada tahap pertama subjek S3 mampu melalui tahap memahami masalah (see) sebagaimana terlihat bahwa subjek mampu menentukan apa yang diketahui yaitu volume air kubus besar $1372 \mathrm{~cm}^{3}$, dan perbandingan volume kubus kecil dan kubus besar yaitu 1:4 dan apa yang ditanyakan yaitu panjang sisi kubus kecil. Selain itu, subjek juga mampu mengidentifikasi informasi apa saja yang diperoleh dari soal untuk menjawab pertanyaan yang diberikan. Pada tahap kedua dalam menyusun rencana pemecahan masalah (plan) subjek S3 tidak mampu melaluinya sebagaimana terlihat dalam wawancara yaitu subjek pertama membagi volume air kubus besar $1372 \mathrm{~cm}^{3}$ dengan perbandingan volume dua kubus 1:4 dan hasilnya $418 \mathrm{~cm}^{3}$. Pada tahap ketiga dalam melaksanakan rencana pemecahan masalah $(d o)$ subjek S3 tidak mampu melaluinya sebagaimana terlihat dalam wawancara tidak terdapat kelanjutan untuk mencari panjan sisi kubus kecil. Selain itu pada tahap keempat dalam memeriksa kembali (check) subjek S3 juga tidak mampu memeriksa kembali hasil pekerjaannya, terlihat 
dari hasil wawancara pada tahap ini subjek tidak melakukan kegiatan memeriksa kembali hasil pekerjaannya.

\section{Deskripsi Soal Nomor 2}

Pabrik susu ABC setiap harinya membutuhkan 15 liter susu segar untuk membuat susu kotak kemasan. Kemasan susu kotak berbentuk balok dengan ukuran $5 \mathrm{~cm} \times 3 \mathrm{~cm} \times 10 \mathrm{~cm}$. Tebal bahan kemasan tipis, sehingga dapat terisi optimal dengan susu segar. Susu kotak tersebut dijual dengan harga Rp.8.000,00 per kotak. Berapa banyak susu kotak kemasan yang dapat diproduksi oleh pabrik setiap harinya?

\section{$\underline{\text { Subjek S1 }}$}

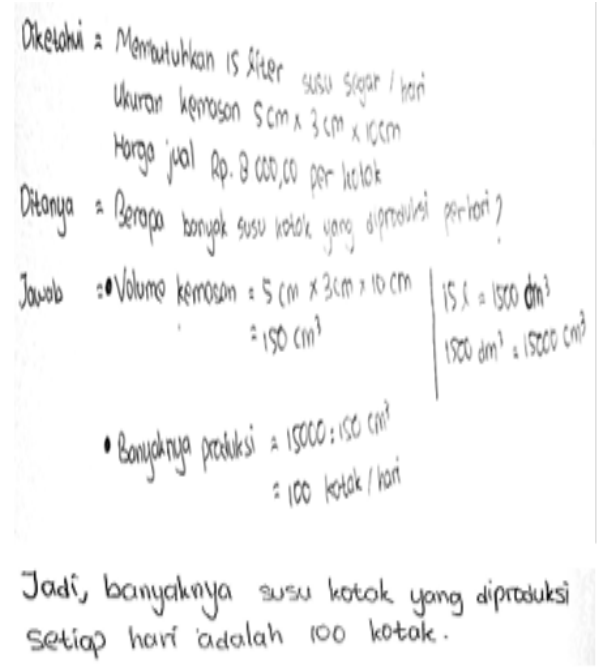

Gambar 4. Hasil Pekerjaan dan Wawancara Subjek S1 Soal Nomor 2

\section{Memahami masalah (See)}

S1: Pada soal nomor 2 diketahui pabrik susu ABC setiap hari membutuhkan 15 liter susu segar, ukuran kemasan berbentuk balok $5 \mathrm{~cm} \times 3 \mathrm{~cm} \times 10 \mathrm{~cm}$, terus harga jual setiap susu kotak Rp.8.000,00.

S1: Lalu yang ditanyakan dari soal yaitu berapa banyak susu kotak yang dapat diproduksi setiap harinya.

\section{Menyusun Rencana Pemecahan Masalah (Plan)}

S1: Pertama mencari volume kemasan susu kotak terlebih dahulu bu, yaitu $5 \mathrm{~cm} \times 3 \mathrm{~cm} \times 10 \mathrm{~cm}=$ $150 \mathrm{~cm}^{3}$. Kemudian saya mengubah satuan dari susu segar yang dibutuhkan setiap harinya bu, liter itukan sama saja $\mathrm{dm}^{3}$ jadi $15 \mathrm{dm}^{3}=15.000 \mathrm{~cm}^{3}$.

\section{Melaksanakan rencana pemecahan masalah (Do)}

S1: Langkah selanjutnya yaitu banyaknya susu segar yang dibutuhkan perhari dibagi dengan volume kemasan susu kotak, sehingga diperoleh hasil 100 kotak per hari bu.

\section{Memeriksa Kembali (Check)}

S1: Iya tadi saya sudah mengecek kembali bu, saya mengerjakan lagi tapi saya tulis di kertas coretcoretan.

Berdasarkan hasil tes dan wawancara soal nomor 2 pada subjek S1 menyelesaikan soal bangun ruang sisi datar konten volume kubus dan volume balok menggunakan langkah-langkah pemecahan 
masalah teori Polya. Pada tahap pertama subjek S1 mampu melalui tahap memahami masalah (see) sebagaimana terlihat bahwa subjek mampu menentukan apa yang diketahui yaitu diketahui pabrik susu $\mathrm{ABC}$ setiap hari membutuhkan 15 liter susu segar, ukuran kemasan berbentuk balok $5 \mathrm{~cm} \times 3 \mathrm{~cm} \times 10$ cm, harga jual setiap susu kotak Rp.8.000,00 dan yang ditanyakan dari soal yaitu berapa banyak susu kotak yang dapat diproduksi setiap harinya. Selain itu, subjek juga mampu mengidentifikasi informasi apa saja yang diperoleh dari soal untuk menjawab pertanyaan yang diberikan. Pada tahap kedua dalam menyusun rencana pemecahan masalah (plan) subjek S1 mampu menggunakan semua informasi yang terdapat pada soal serta dapat menentukan strategi untuk menyelesaikan soal tersebut dengan cara pertama mencari volume kemasan susu kotak terlebih dahulu yaitu $5 \mathrm{~cm} \times 3 \mathrm{~cm} \times 10 \mathrm{~cm}=150 \mathrm{~cm}^{3}$. Kemudian subjek mengubah satuan dari susu segar yang dibutuhkan setiap harinya dari liter menjadi $\mathrm{dm}^{3}$ lalu mengubah $\mathrm{dm}^{3}$ menjadi $\mathrm{cm}^{3}$ sehingga memperoleh hasil $15 \mathrm{dm}^{3}=15.000 \mathrm{~cm}^{3}$. Pada tahap ketiga dalam melaksanakan rencana pemecahan masalah (do) subjek S1 mampu menggunakan rencana pemecahan masalah yang sudah disusun pada tahap sebelumnya untuk menyelesaikan soal dengan cara membagi banyaknya susu segar yang dibutuhkan perhari dengan volume kemasan susu kotak sehingga diperoleh hasil 100 kotak per hari. Namun pada tahap keempat dalam memeriksa kembali (check) subjek S1 tidak mampu memeriksa kembali hasil pekerjaannya. Pada tahap ini subjek hanya mengecek dan mengerjakan kembali dengan cara yang sama.

\section{Subjek $\mathbf{S 2}$}

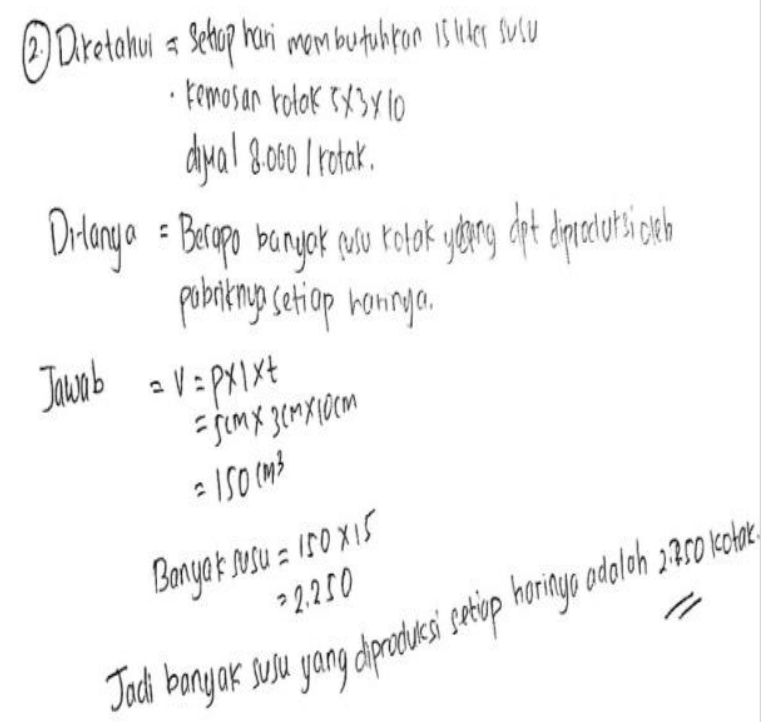

Gambar 5. Hasil Pekerjaan dan wawancara Subjek S2 Soal Nomor 2

\section{Memahami Masalah (See)}

S2: Soal nomor 2 diketahui pabrik susu membutuhkan 15 liter susu segar setiap harinya, ukuran kemasan berbentuk balok $5 \mathrm{~cm} \times 3 \mathrm{~cm} \times 10 \mathrm{~cm}$, dan harga jual Rp.8.000,00 per kotak kemasan susu.

S2: Yang ditanyakan dari soal nomor 2 yaitu banyak susu kotak yang dapat diproduksi setiap hari.

\section{Menyusun Rencana Pemecahan Masalah (Plan)}

S2: Pertama mencari volume kemasan susu kotak terlebih dahulu bu, yaitu $5 \mathrm{~cm} \times 3 \mathrm{~cm} \times 10 \mathrm{~cm}=$ 
Analisis Kemampuan Pemecahan Masalah Siswa SMP Kelas VIII Pada Materi Bangun Ruang Sisi Datar Ditinjau dari Kecerdasan Logis Matematis, Riyani Rinawati, Novisita Ratu

$150 \mathrm{~cm}^{3}$.

\section{Melaksanakan Rencana Pemecahan Masalah (Do)}

S2: Untuk mencari banyak susu yang bisa diproduksi oleh pabrik setiap harinya saya menggunakan cara perkalian antara volume kemasan kotak susu dengan susu yang dibutuhkan oleh pabrik setiap harinya bu.

\section{Memeriksa kembali (Check)}

S2: Tidak bu.

Berdasarkan hasil tes dan wawancara soal nomor 2 pada subjek S2 menyelesaikan soal bangun ruang sisi datar konten volume kubus dan volume balok menggunakan langkah-langkah pemecahan masalah teori Polya. Pada tahap pertama subjek S2 mampu melalui tahap memahami masalah (see) sebagaimana terlihat bahwa subjek mampu menentukan apa yang diketahui yaitu diketahui pabrik susu membutuhkan 15 liter susu segar setiap harinya, ukuran kemasan berbentuk balok $5 \mathrm{~cm} \times 3 \mathrm{~cm} \times 10$ $\mathrm{cm}$, dan harga jual Rp.8.000,00 per kotak kemasan susu dan yang ditanyakan dari soal yaitu 2 yaitu banyak susu kotak yang dapat diproduksi setiap hari. Selain itu, subjek juga mampu mengidentifikasi informasi apa saja yang diperoleh dari soal untuk menjawab pertanyaan yang diberikan. Pada tahap kedua dalam menyusun rencana pemecahan masalah (plan) subjek S2 mampu menggunakan semua informasi yang terdapat pada soal serta dapat menentukan strategi untuk menyelesaikan soal tersebut dengan cara pertama mencari volume kemasan susu kotak terlebih dahulu bu, yaitu $5 \mathrm{~cm} \times 3 \mathrm{~cm} \times$ $10 \mathrm{~cm}=150 \mathrm{~cm}^{3}$. Pada tahap ini subjek kurang tepat dalam menyusun rencana pemecahan masalah karena terdapat langkah yang tidak dituliskan subjek yaitu tidak mengubah satuan susu segar yang diperlukan setiap hari dari liter menjadi $\mathrm{cm}^{3}$. Pada tahap ketiga dalam melaksanakan rencana pemecahan masalah (do) subjek S2 tidak mampu melaluinya sebagaimana terlihat pada hasil wawancara subjek melakukan penyelesaian dengan cara menggunakan cara perkalian antara volume kemasan kotak susu dengan susu yang dibutuhkan oleh pabrik setiap harinya. Hal yang dilakukan subjek pada tahap ini tidak tepat. Pada tahap keempat dalam memeriksa kembali (check) subjek S2 juga tidak mampu memeriksa kembali hasil pekerjaannya. Pada tahap ini subjek tidak melakukan kegiatan memeriksa kembali hasil pekerjaannya.

\section{Subjek S3}

\section{Memahami masalah (See)}

S3: Nomor 2 diketahui pabrik susu membutuhkan 15 liter susu segar setiap harinya, ukuran kemasan berbentuk balok $5 \mathrm{~cm} \times 3 \mathrm{~cm} \times 10 \mathrm{~cm}$, dan harga jual Rp.8.000,00 per kotak kemasan susu bu.

S3: Ditanyakan dari soal nomor 2 yaitu banyak susu kotak yang dapat diproduksi setiap hari.

\section{Menyusun rencana pemecahan masalah (Plan)}

S3: Saya gunakan volume balok untuk mencari volume kemasan susu bu, yaitu $5 \mathrm{~cm} \times 3 \mathrm{~cm} \times$ $10 \mathrm{~cm}=150 \mathrm{~cm}$. 


\section{Melaksanakan rencana pemecahan masalah (Do)}

S3: Setelah saya menemukan volume kemasan susu lalu saya kalikan dengan harga per kotak bu.

S3: Hasil perkalian antara volume kemasan susu dengan harga susu kemudian saya bagi dengan jumlah susu yang diperlukan setiap harinya untuk mengetahui jumlah kemasan susu kotak yang diproduksi setiap hari.

\section{Memeriksa kembali (Check)}

S3: Tidak bu.

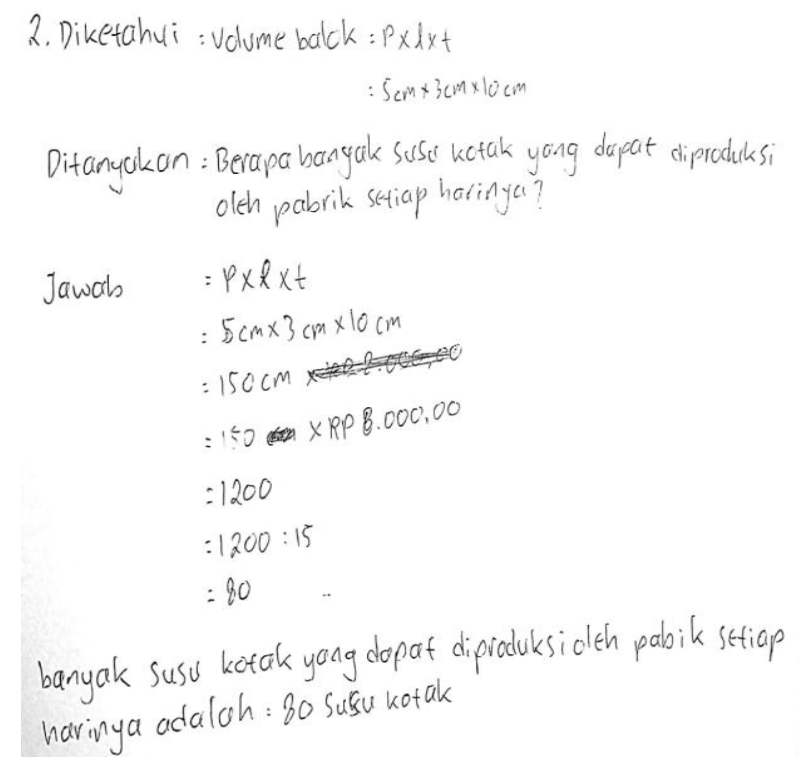

Gambar 5. Hasil Pekerjaan dan wawancara Subjek S3 Soal Nomor 2

Berdasarkan hasil tes dan wawancara soal nomor 2 pada subjek S3 menyelesaikan soal bangun ruang sisi datar konten volume kubus dan volume balok menggunakan langkah-langkah pemecahan masalah teori Polya. Pada tahap pertama subjek S3 mampu melalui tahap memahami masalah (see) sebagaimana terlihat bahwa subjek mampu menentukan apa yang diketahui yaitu diketahui pabrik susu membutuhkan 15 liter susu segar setiap harinya, ukuran kemasan berbentuk balok $5 \mathrm{~cm} \times 3 \mathrm{~cm} \times 10$ $\mathrm{cm}$, dan harga jual Rp.8.000,00 per kotak kemasan susu dan apa yang ditanyakan yaitu banyak susu kotak yang dapat diproduksi setiap hari. Selain itu, subjek juga mampu mengidentifikasi informasi apa saja yang diperoleh dari soal untuk menjawab pertanyaan yang diberikan. Pada tahap kedua dalam menyusun rencana pemecahan masalah (plan) subjek S3 tidak mampu melaluinya sebagaimana terlihat dalam wawancara yaitu subjek hanya menjelaskan sebagaimana yang dituliskan pada lembar jawaban yaitu volume balok untuk mencari volume kemasan susu yaitu $5 \mathrm{~cm} \times 3 \mathrm{~cm} \times 10 \mathrm{~cm}=150 \mathrm{~cm}$, satuan yang digunakan seharusnya $\mathrm{cm}^{3}$. Pada tahap ketiga dalam melaksanakan rencana pemecahan masalah (do) subjek S3 tidak mampu melaluinya sebagaimana terlihat dalam wawancara subjek melakukan penyelesaian dengan cara mengalikan volume kemasan dengan harga susu setiap kemasan. Hal yang dilakukan subjek pada tahap ini tidak tepat. Pada tahap keempat dalam memeriksa kembali (check) subjek S3 juga tidak mampu memeriksa kembali hasil pekerjaannya, terlihat dari hasil wawancara pada tahap ini subjek tidak melakukan kegiatan memeriksa kembali hasil pekerjaannya. 
Berdasarkan hasil penelitian di atas dapat dilihat bahwa tingkat kecerdasan logis matematis siswa menentukan kemampuannya dalam menyelesaikan masalah, semakin tinggi kecerdasan logis matematis yang dimiliki oleh siswa semakin baik pula siswa dalam melakukan pemecahan masalah. Sejalan dengan pendapat Toyib et al., 2019, kecerdasan logis matematis memiliki peran dan konstribusi dalam kemampuan pemecahan masalah. Hal ini terbukti bahwa siswa dengan tingkat kecerdasan logis matematis tinggi (S1) mampu melalui tahapan memahami masalah, menyusun rencana pemecahan masalah, melaksanakan rencana pemecahan masalah, namun tidak mampu melalui tahapan memeriksa kembali. Siswa dengan tingkat kecerdasan logis matematis sedang (S2) mampu melalui tahapan memahami masalah, menyusun rencana pemecahan masalah, melaksanakan rencana pemecahan masalah tetapi pada soal nomor 2 tidak mampu melaluinya, tidak mampu melalui tahapan memeriksa kembali. Sedangkan siswa dengan kecerdasan logis matematis rendah (S3) hanya mampu melalui tahapan memahami masalah.

\section{KESIMPULAN}

Berdasarkan hasil penelitian yang telah dilakukan dapat disimpulkan bahwa kemampuan pemecahan masalah siswa SMP pada materi bangun ruang sisi datar konten volume kubus dan volume balok ditinjau dari kecerdasan logis matematis menunjukkan hasil yang berbeda-beda pada setiap subjek. Adapun kesimpulan hasil penelitian mengenai kemampuan pemecahan masalah siswa SMP pada materi bangun ruang sisi datar konten volume kubus dan volume balok ditinjau dari kecerdasan logis matematis sebagai berikut:

1. Subjek S1 mampu melalui tahapan memahami masalah, mampu melalui tahapan menyusun rencana pemecahan masalah, dan tahapan melakasanakan rencana pemecahan masalah untuk soal nomor 1 dan soal nomor 2. Akan tetapi subjek S1 tidak mampu melewati tahap memeriksa kembali untuk soal nomor 1 dan soal nomor 2.

2. Subjek S2 mampu melalui tahapan memahami masalah untuk soal nomor 1 dan nomor 2 , mampu melalui tahapan menyusun rencana pemecahan masalah untuk soal nomor 1 dan untuk soal nomor 2, mampu melalui tahapan melaksanakan rencana pemecahan masalah untuk soal nomor 1 dan tidak mampu melalui melakukan rencana pemecahan masalah untuk soal nomor 2, tidak mampu memeriksa kembali untuk soal nomor 1 dan soal nomor 2.

3. Subjek S3 mampu melalui tahapan memahami masalah untuk soal nomor 1 dan soal nomor 2, tidak mampu melalui tahapan menyusun rencana pemecahan masalah untuk soal nomor 1 dan soal nomor 2, tidak mampu melalui tahapan melaksanakan rencana pemecahan masalah untuk soal nomor 1 dan soal nomor 2, tidak mampu melalui tahapan memeriksa kembali untuk soal nomor 1 dan soal nomor 2 .

\section{REFERENSI}

Asis, M., Arsyad, N., Studi, P., Matematika, P., Program, D., Universitas, P., Makassar, N., Geometri, 
M., Logis, K., \& Gender, P. (2015). Profil Kemampuan Spasial Dalam Menyelesaikan MAsalah Geometri Siswa Yang Memiliki Kecerdasan Logis Matematis Tinggi Ditinjau Dari Perbedaan Gender. Jurnal Daya Matematis, 1 , 2 , 3 1. 3, 78-87.

Cahyono, B., \& Adilah, N. (2016). Analisis Soal Dalam Buku Siswa Matematika Kurikulum 2013 Kelas VIII Semester I Berdasarkan Dimensi Kognitif Dari TIMSS. JRPM (Jurnal Review Pembelajaran Matematika, 1(1), 86-98.

Faizah, F., Sujadi, I., \& Setiawan, R. (2017). Proses Berpikir Siswa Kelas VII E Dalam Memecahkan Masalah Matematika Pada Materi Pecahan Ditinjau Dari Kecerdasan Logis Matematis. Jurnal Pendidikan Matematika dan Matematika (JPPM), 4, 15-25.

Hidayat, W., \& Sariningsih, R. (2018). Kemampuan Pemecahan Masalah Matematis Dan Adversity Quotient Siswa Melalui Pembelejaran OPEN ENDED. Jurnal JNPM (Jurnal Nasional Pendidikan Matematika, 2(1), 109-118.

Komang, N., Dwianjani, V., \& Candiasa, I. M. (2018). Identifikasi Faktor-Faktor yang Mempengaruhi Kemampuan Pemecahan Masalah Matematika. Jurnal Pendidikan Sains \& Matematika, 2(2), 153 166.

Mahardhikawati, E., Mardiyana;, \& Setiawan, R. (2017). Analisis Kemampuan Pemecahan Masalah Berdasarkan Langkah-langkah POLYA Pada Materi Turunan Fungsi Ditinjau Dari Kecerdasan Logis-Matematis Siswa Kelas XII IPA SMA Negeri 7 Surakarta Tahun Ajaran 2013/2014. Jurnal Pendidikan Matematika dan Matematika (JPPM), 4, 119-128. https://doi.org/10.4135/9781483365817.n1278

Mariam, S., Nurmala, N., Nurdianti, D., Rustyani, N., Desi, A., \& Hidayat, W. (2019). Analisis Kemampuan Pemecahan Masalah Matematis Siswa MtsN Dengan Menggunakan Metode Open Ended Di Bandung Jawa Barat. Jurnal Cendekia: Jurnal Pendidikan Matematika, 3(1), 178-186.

Nissa, I. C. (2015). Pemecahan Masalah Matematika Teori dan Contoh Praktik (p. 19). MataramLombok-NTB: Duta Pustaka Ilmu

OECD. (2012). PISA 2012 Assesment and Analytical Framework: Mathematics, Reading, Science, Problem Solving and Financial Literacy. Paris. OECD

OECD. (2015). PISA 2015 Assesment and Analytical Framework: Mathematics, Reading, Science, Problem Solving and Financial Literacy. Paris. OECD 
Analisis Kemampuan Pemecahan Masalah Siswa SMP Kelas VIII Pada Materi Bangun Ruang Sisi Datar Ditinjau dari Kecerdasan Logis Matematis, Riyani Rinawati, Novisita Ratu

Sumartini, T. S., \& Matematis, K. P. (2016). Peningkatan Kemampuan Pemecahan Masalah Matematis Siswa melalui Pembelajaran Berbasis Masalah. Jurnal Pendidikan Matematika STKIP Garut, 5.

Susanti, V. D. (2018). Analisis Kemampuan Kognitif Dalam Pemecahan Masalah Berdasarkan Kecerdasan Logis-Matematis. Jurnal Matematika dan Pendidikan Matematika, 3(1), 71-83.

Toyib, M., Rohman, N., \& Sutami, S. (2019). Kemampuan Pemecahan Masalah Matematika Model TIMSS Konten Bilangan Pada Siswa Dengan Kecerdasan Logis Matematis Tinggi, Jurnal Penelitian Dikdatik Matematika, 1), 2), 3). 3(2), 64-80. 